British Journal of Marketing Studies

Vol. 10, Issue 1, pp.13-31, 2022

Print ISSN: 2053-4043(Print),

Online ISSN: 2053-4051(Online)

\title{
POLITICAL PARTY BRAND COMPETENCE AND VOTERS' DECISION MAKING IN NIGERIA
}

\author{
Adiele Austine Opara, PhD. \\ Department of Marketing, Faculty of Management Sciences, Rivers, State University, \\ Nkpolu- Oroworukwo, PMB 5080, Port Harcourt, Nigeria
}

Citation: Adiele Austine Opara (2021) Political Party Brand Competence and Voters' Decision Making In Nigeria, British Journal of Marketing Studies, Vol. 10, No.1, pp.13-31

\begin{abstract}
This study examined the relationship between political party brand competence and voters' decision making in Nigeria. The study adopted a cross-sectional survey in its investigation of the variables. Primary data was generated through structured questionnaire. The target population of this study was eighty four million, four thousand and eighty four $(84,004,084)$. Given an accessible population of twenty six million, six hundred and thirty four thousand six hundred and five $(26,634,605)$ within the six geo-political zones in Nigeria, the sample size of 384 was determined using calculated using the Taro Yamane's formula for sample size determination. The reliability of the instrument was achieved by the use of the Cronbach Alpha coefficient with all the items scoring above 0.70. The hypotheses were tested using the Pearson Product Moment Correlation Coefficient with the aid of Statistical Package for Social Sciences version 23.0. The tests were carried out at a $95 \%$ confidence interval and a 0.05 level of significance. The findings revealed that there is a significant political party brand competence and voters' decision making in Nigeria. The study concludes that when political parties adopt and build brand competence it has a positive influence on voters' decision making in Nigeria. The study recommends that political parties should always present brands (candidates) for elective positions based on personality of such candidates especially with regards to brand competence.
\end{abstract}

KEYWORDS: political party brand competence, voters' decision making, classical rational decision, confirmatory decision making, fast and frugal decision making

\section{INTRODUCTION}

President Abraham Lincoln in his Gettysburg address professed "ours is a government of the people by the people by the people and for the people "that to many has become the definition of democracy (Gienapp, 2002) as cited in Epstein (2011). In a constitutional democracy, the primary objective of government is to satisfy the people. Political legitimacy is secured by majority of the people, they constitute the political market and are saddled with the responsibility of deciding who would lead and represent their interest in governance (Achor, Nwachukwu \& Udensi, 2017). Reeves and De Chernatony (2009) submit that political thespians can control and adapt to the dynamics of the political market if they perceive voters as their target market and ensure to satisfy, institute, and sustai9n a long-lasting sincere relationship with them.

@ECRTD-UK https://www.eajournals.org/

ULR: https://doi.org/10.37745/bjms.2013 
British Journal of Marketing Studies

Vol. 10, Issue 1, pp.13-31, 2022

Print ISSN: 2053-4043(Print),

Online ISSN: 2053-4051(Online)

Aristotle contended that in politics, to secure the solidity of the constitution, there is a system education suitable to the constitution. To accentuate the importance of education in maintaining a steady socio-political order (Ibeanu\& Orji, 2014). Alexis de Tocquebville in Lewis (2008) upheld that most electoral systems would have one better had the existence of educational institutions preceded those of courts. The level of political participation is habitually sturdily correlated with the level of literacy of a population. Democratic nations around the world have used education as a tool for creating responsible and supportive citizenship (Osborne 2000). The Nigerian constitution and international human rights law uphold that the right to vote and be voted for is attained at the age of eighteen (18) years. Therefore, elections indicate the level of political awareness and participation of the citizenry. Voting is the legal, political and social mechanism through which the citizens can express their participation in elections, exercise their interests and needs to their leaders (Bassey \& Samuel, 2011).

Borhaug (2005) submits that it is important to educate citizens to be politically engaged, active and interested in participating in the political system to build political competence (Solhung 2003). Voters' education creates the knowledge basis for citizens' political participation to help make individual political activity intelligible (McGraw 2000; Monroe, Hankin \& Vechten, 2000). However, the knowledge structures acquired from voters' education emanate from individual perceptions and interpretations and may thus differ from one individual to the next (TorneyPurta,1992). In order to develop these structures each individual must be exposed to ideas and representations of the political world Niemi \& Junn (1998) as cited in (Borhaug, 2005). Participatory democracy cannot be achieved without political participation and brand development as brands determine how consumers (voters) perceive products and services.

This is because in elections voters choose among competing political actors who are aligned in [political parties competing for votes (Achor, Nwachukwu \& Udensi, 2017). De Chernatony and McDonald (2000) Submits that during a blind test (brands were hidden) most consumers preferred Pepsi over coke but when the brands were exposed, consumers choose coke over Pepsi. Voters are motivated to patronize a political organization or candidate based on their knowledge of the political party brand personality in the political market (Gareth, 2009). Lees-Marshment (2003/2004) submits that the political market is made up of political party staff, appointees who carry out the individual and shared political interest of their parties and affiliated factions. The external political market on the other hand consists of international organizations agencies such as United Nations (UN) and the public, mass media, internet users, opposition parties etc (Nyarwi, 2015).Therefore, political parties and candidates seeking to dominant in the political space cannot avoid marketing. Smith (2009) indicates that political parties are organizations in which political actors seek to interchange ideas, policies and promises for public support. Therefore, the process of analyzing, developing, implementing and managing strategic campaigns to achieve the objectives of guiding public opinion, satisfy the needs and expectations of the voting public, uphold party principles, winning elections, making laws and referendums is paramount (Winchester, Hall \& Binney, 2016). Strategic political campaigns offer political parties and candidates to the political market by utilizing the appropriate marketing strategies and tactics to achieve voters' conversion, acquisition, retention and loyalty (Kotler, 1975). These political

@ECRTD-UK https://www.eajournals.org/

ULR: https://doi.org/10.37745/bjms.2013 
British Journal of Marketing Studies

Vol. 10, Issue 1, pp.13-31, 2022

Print ISSN: 2053-4043(Print),

Online ISSN: 2053-4051(Online)

campaigns are anchored on the political party brand personality with a thorough understanding of their target market (voters) needs, wants, perception, and preferences (Kotler, 1975).

Achor, et al. (2017) argued that political parties and candidates are established as grands through their names, logo, ideologies, personality which supposedly communicate a message to enlightened voters, party supporters and other stakeholders. Based on the political party brand personality, voters, can make a choice amongst various political parties and candidates in the interest of good governance (Kotler, 1975). Academic scholars in the field of political science and political marketing have explored various determinants of the voters' decision making process (Downs, 1957, Andrew, 2013; Gorbaniuk, Kusak, Kogut \& Kustos, 2014; Guzment et al, 2014; Cwalina \& Falkowski, 2014; Opkara, Anuforo \& Achor, 2016; Nwachukwu, Achor, Nkwocha \& Okwara, 2016). These pundits indicated that the political party and candidates' ability to develop and adopt top-notch political campaigns to garner support and loyalty, sell party manifestoes, and maintain consistent relevance, influence voters' decision making in the political market (Achor, et al. 2017). This study therefore examined the relationship between political party brand competence and voters' decision-making in the context of Nigeria political environment.

Specifically, the following objectives were to:

i. Examine the relationship between political party brand competence and voters' classic rational choice in Nigeria.

ii. Determine the relationship between political party brand competence and voters' confirmatory decision making in Nigeria.

iii. Investigate the relationship between political party brand competence and voters' fast and frugal decision in Nigeria.

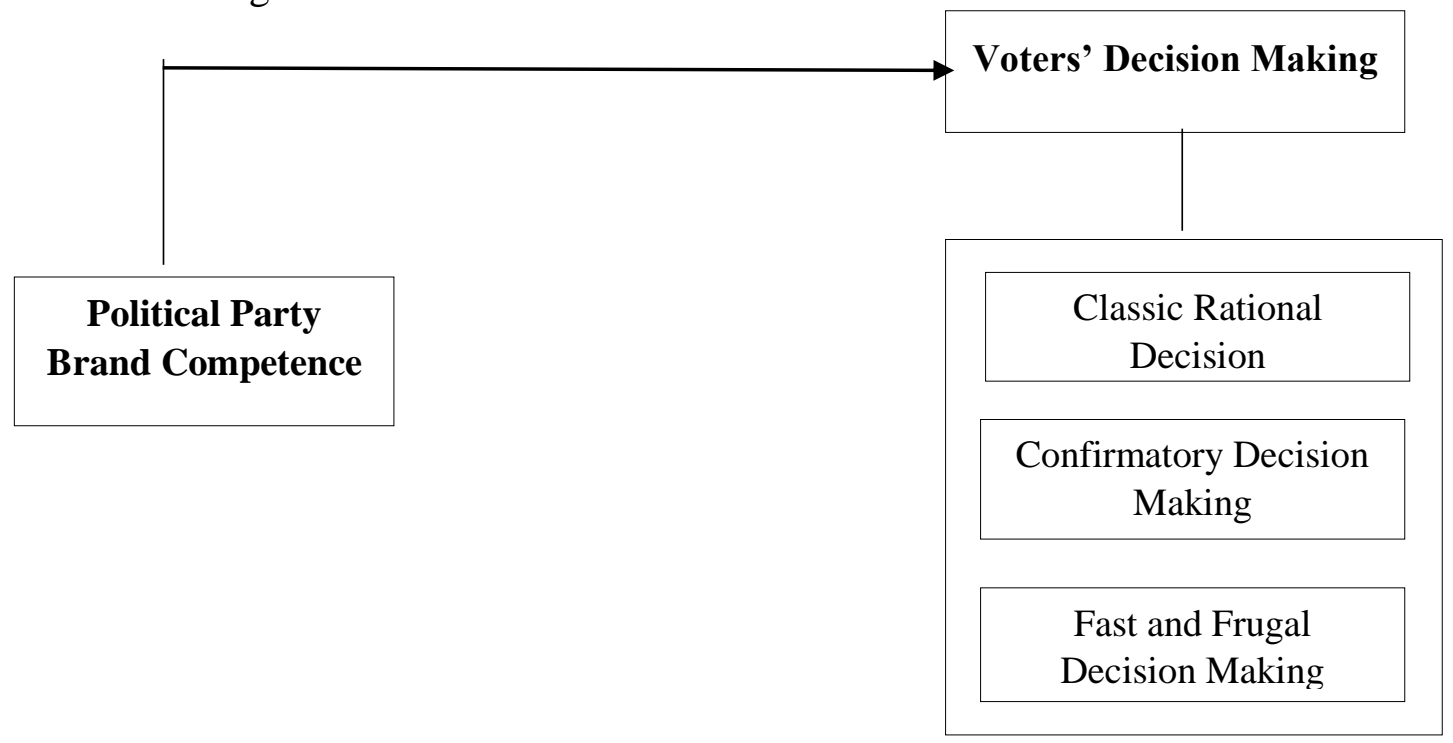

Figure 1 Conceptual model for political party brand competence and voters' decision making

Source: Researcher (2021)

\section{LITERATURE REVIEW}

@ECRTD-UK https://www.eajournals.org/

ULR: https://doi.org/10.37745/bjms.2013 
British Journal of Marketing Studies

Vol. 10, Issue 1, pp.13-31, 2022

Print ISSN: 2053-4043(Print),

Online ISSN: 2053-4051(Online)

\section{Theoretical Foundation}

\section{Rational Choice Theory (RCT)}

The rational choice theory can be traced back to the writings of early philosophers; Adam Smith, John Locke, Thomas Hobbes, William Stanley Jevons, and Gary Becker (Becker 1976). They proposed that people make consumption decisions mainly to maximize utility and it subsequently developed into neoclassical economics (Grune-Yanoff, 2012). The rational choice approach has grown beyond conservative economic issues (Green, 2002 citing, Becker 1976; Radnitzky \& Bernholz, 1987; Hogarth \&Reder, 1987; Swedberg, 1990; Green \& Shapiro, 1996). Rational choice theory is a basis for understanding the socio-economic behavior of people. The fundamental proposition of the theory is that collective social behavior is as a result of the behavior of individual members of the society (Michael, 2013). Different scholars of the rational choice theory have their various assumptions about individuals and organizations, but each supposition originates from the individual as the fundamental unit of the theory (Abell, 2000). Elster (1989) submitted that the essence of the rational choice theory is that when people are confronted with different courses of action, they do what they think has the best inclusive consequence. The rational choice theory assumes that every person has preferences among various available alternatives choices that allows them to state which option they prefer (Rafael, 2015).

The theory is focused on the elements of individual choices called methodological individualism. Abell, structures and standards, which regulate a particular course of action, are simply exceptional cases of Oone choice. To the rational choich theory, rationality indicates that people respond to stimuli as if they are balancing costs against paybacks to arrive at actions that exploit personal benefits (Friedman, 1953). According to Rafael, (2015) some assumptions of RCT include (1) people have selfish preferences, (2) they tend to first maximize their own utility, and (3) they behave independently based on their level of education. Rational choice theory has become increasingly employed in social sciences other than economics, such as sociology, evolutionary theory, and political science in recent decades (Aki \& Jaakko, 2007). It was first applied to understand voters' behavior and party competition by Anthony Downs in 1957. Since then it has developed into a paradigm of analysis in the political science (Downs, 1957). It has had farreaching impacts on the study of political science, especially in fields like the study of interest groups, elections, behavior in legislatures, coalitions, and bureaucracy (Dunleavy,1991). In these fields, the use of the rational choice paradigm to explain broad social phenomena is the subject of active controversy. Other directions in which rational choice theory has gone away from the works of Downs include areas of collective action, public choice, rent seeking, among others (Jhingan, 2013).

\section{The Concept of Political Party Brand Personality}

Based on self-organization theory, personality can be determined by stabilized behavioral patterns (Li, \& Ahlstrom, 2016). Marco, Frank and Alexander (2011) argued that personality variables that were traditionally premeditated by psychologists and merged recently by economists and business practitioners should be linked with the brand. Allen \& Olson, (1995) defined personality as a set of implications created by an observer to extrapolate the inward characteristics of another person.

@ECRTD-UK https://www.eajournals.org/ 
British Journal of Marketing Studies

Vol. 10, Issue 1, pp.13-31, 2022

Print ISSN: 2053-4043(Print),

Online ISSN: 2053-4051(Online)

Some empirical indications found that personality variables paly vital roles in business processes (Blachflower \& Oswald, 1998, Zhao \& Seibert 2006). Rauch and Frese (2007). Submitted that "the person component" should be domiciled in business research because success as a political brand is not a random process of actions but is critically influenced by personality. Nwachukwu, Achor, Nkwocha and Okwara (2016) indicated that the political party brand personality is wider than the product, while a political product has different parts like the politician, political policy, party manifestoes: a brand is intangible and psychological.

David Heller in Allen (2013) argues that politics is about symbolism as opposed to actual policy implementation. Images are more transparent than content, it sends messages about who politicians are, and is important to them. An important component of a brands image is its brand personality (Keller, 1993). Therefore, politicians can be viewed as 'actors' acting out in a purpose way to achieve programmed party-political goals and objectives (O'shaughnessy, 2003). Political actors and parties have palpable personalities which helps to create perception about them. The political party brand personality must be in consonance with political brand image (Jain, Pich, Ganesh \& Armannsdottir, 2017). And that is the essence of the political party brand personality (Skarzynska, 2004, Schneider, 2004]. The political party brand personality creation is established by the same process as human personality. It has to do with the personification 0 f the brand based on the brand's observed behaviours, allowing human traits to be inferred from action or stated intended action [smith, 2009]. Personality traits are created mentally by voters who make inferences based on their observation of the behavior of political actors (Aaker, 1997). Hence, the perception, reception and rejection of the political candidate can be braced by the voters (Jain, et al 2017).

Political party brand personality is a structure, which illustratesthat brand can possess humanbased attributes. Apparently, voters seek some qualities in the political brands to deal with the mental and material dimensions of politics (Ahmad \& Thyagaraji, 2015). Aaker [1997] indicated that a political party brand personality is the set of human characteristics associated with a brand. Explicit appeals like, kind, welcoming and courteous, well-informed, effective and efficient have the chance of universality (Davies, Rojas-Mendez, Whelan, Mete \&Loo, 2018). Nyarwi (2015) submitted that a political party brand personality is an associative network of the human characteristics relating to a political party, held in memory and accessible when stimulated from the memory of a voter.

Nwachukwun et al (2016) indicated that the political party brand personality is the overarching human feeling, impression, association, or image the public has towards a politician, or political organization. Political parties and their candidates are modeled as brands through their names and ideological pastures which supposedly communicate a message to voters, and other stakeholders [smith 2009]. The past and present human behavior linked with a party affects as a brand. The personalities that make up the leadership structure of the party also account for whether such a party will be seen as a brand worthy of being patronized or not (Akhmad \& Azhar, 2015). Yesil and Sozbilir (2013) opined that political party brand personality dimensions in politics.

@ECRTD-UK https://www.eajournals.org/

ULR: https://doi.org/10.37745/bjms.2013 
British Journal of Marketing Studies

Vol. 10, Issue 1, pp.13-31, 2022

Print ISSN: 2053-4043(Print),

Online ISSN: 2053-4051(Online)

The political party brand personality has direct influence on voters' intention because of the ability to create favorable associations in voters' memory (Keller, 1993; 2003; Phau, 2000). Collins and Loftus, (1975) submitted that brand knowledge is made from individual pieces of informational referred to as nodes that link together in memory to form more complex associative networks [Wyer and Srull, 1989]. Information is recalled from a memory when a node is stimulated from rest by the activation process (De Groot, 1989). Ruther, Hanretty and Lettice (2015) adopted Aaker's brand personality model to explore brand positions in the political market. They found that the two main dimensions on which parties brand personalities differ relate to the trade-off between communicating competence and communicating sincerity and between communicating sophistication and communicating ruggedness. Political party brand personality attributes are feelings attached to a political brand, and the functionality of such brand to some extent depend on the (Cornfield, 2017). For a political candidate or party to achieve a phenomenal support in the vote market, the candidate or party must have brand image, which is the impression the candidate or party creates in the minds of the voters; the political party brand dimensions help voter form robust opinions about a candidate or party (Achor, et al. 2017).

\section{Political Party Brand Competence}

The concept of competence is the ability or capability, which enhances the satisfactory performance and completion of some tasks. Although the performance of tasks is directly observable abilities or capabilities that underlie the performance are essentially inferred (Hager \& Gonezi, 1996). Epstein \&Hundert, (2002) as cited in Yuanjing (2012) defined competence as the typical and thoughtful use of communication, knowledge technical skills, clinical reasoning, emotion, values, and reflection in daily encounters and in the performance of a tasks. Roth (1917) as cited in Hartig, Klieme and Leutner (2008) opine that competence is individual capability as it relates to dispositions for your own action and judgment. Furthermore, Hartig, et al. (2008) indicate that maturity should be inferred as competence in three ways: a) self-competence - the ability to take full responsibility of your own action, b) professional competence - the ability to judge in a particular vocation, and be responsible, c) social competence - the ability to conduct oneself and be decisive, and be responsible, in career, societal or political terms. McClelland, (1973) opined that competence are qualities essential for successfully performing activity. From his view point any personal characteristics can be considered "competence" in as much as it enhances and predict success in actual achievement.

Weinert (2001) opined that when competence is considered in the context-dependent ability constructs; it can only be developed through learning process where the individual cooperates with his/ her environment. In other words competence can be acquired through learning or competence can be attained by experience gained from relevant circumstances of demand and they might be influenced by training or other external interventions, by years of practice they might be enhanced to an expertise in the respective domains. Spady (1994) as cited in Vare, Arro, Hammer, Gobbo, Vries, Farioli, Kadji - Mayer, Millican, Nijdam, Reji and Zachariou (2019) opined that competence is considered a combination of knowledge, skills, attitudes that facilitates the performance tasks and solve problems successfully. Competence is the focused knowledge a person has as acquired that enhances his / her cognitive performance, a high level of competence

@ECRTD-UK https://www.eajournals.org/ 
British Journal of Marketing Studies

Vol. 10, Issue 1, pp.13-31, 2022

Print ISSN: 2053-4043(Print),

Online ISSN: 2053-4051(Online)

breeds expertise (Mayer, 2003). Simonton (2003) indicated that competence is a set of assimilated skills and knowledge that creates an important aspect of performance or achievement in each field. Accordingly, to Sleurs (2008) competence is a concept that should not be taught but should be seen, as necessary. In argument with Sleurs (2008), Adombent and Hoffiman (2013) opined that is impossible to communicate competence because it can only be developed. In other derwords, competence cannot be imparted but it can be learned. Similarly, Barth, Godeman, Rieckman and Stoltenberg (2007) considered competence as the interface betweenthe cognitive structure of mental models and non-cognitive component. The achievement and development of competence is a process by which people exhibit behaviours and attitudes beyond their inherent abilities which aids in the successful performance of their tasks.

Yuanjing (2012) submitted that competence is an abstract concept that involves broad capabilities, knowledge, skills, and attitudes. The Organization for Economic Cooperation and Development (OECD) submitted that competence is the key to successful life and a well-functioning society.in 1997, (OECE) introduced the defining key competence project (DeSeCo) which provides a conceptual framework fordescribing and appraising competence. They include the following: knowledgeabout systems, future thinking, participation in decision making, attentiveness, empathy engagement, trans-disciplinary, innovativeness, action critical thinking, responsibility, decisiveness (Richen \& Salganik, 2003).

\section{Classic rational Choice Decision- Making}

Rational choice theory has been claimed to be the prevailing view on the political science today (Brogan, 2001). Michael, (2013) indicated that the classic rational choice is a growing paradigm in political science and can be applied to a range of areas in the discipline, especially, voting behavior, policy formulation and implementation, rule formation, amongst others. Classic rational choice began with Downs' (1957) classic study on economic rationality, he argued that rationality is measured by how voters strive for what they desire, or at least

\section{Classic Rational Choice Decision-Making}

Rational choice theory has been claimed to be the prevailing view in political science today (Brogan, 2001). Michael (2013) indicated that the classic rational choice is a growing paradigm in political Science and can be applied to a range of areas in the discipline, especially, voting behavior. Policy formulation and implementation, rule formation, among others. Classic rational choice began with Downs' (1957) classic study on economic rationality, he argued that rationality is measured by how voters Strive for what they desire, or at least act as if they were pursuing some end based on the information available to them (Brams, 1987). Edlin, Gelman and Kaplan (2007) proved that voting is considered rational when voters have 'social' preferences and are concerned about social welfare. Classic rational choice involves actively gathering as much information as one possibly can about every candidate/party on the ballot (Lau, et al 2013). In other words, classic rational choice has to do with making voters decisions after deep, comparable search. Leiter, (2013) refers to the set of voters who are likely to be more aware of parties ideological and policy sophisticated voters". Lau and Redlawsk (2001) indicated that voters who make classic rationalchoices gather and process ideological information and have a greater incentive to use

@ECRTD-UK https://www.eajournals.org/ 
British Journal of Marketing Studies

Vol. 10, Issue 1, pp.13-31, 2022

Print ISSN: 2053-4043(Print),

Online ISSN: 2053-4051(Online)

thisinformation in making voting decisions. Classic rational choice involves weighing positiveand negative qualities associated with each political party/candidate based on the information available (Chong 2013). With the classic rational choice strategy, there is no room for emptionor other variables that could influence the active processing of the information. Downs noted several emotional factors that could influence rational behavior but claimed that he was only looking from a political rather than a psychological perspective (Downs, 1957). Emotion has not been considered as acomponent of decision making within the rational choice paradigm: instead it has been broadly perceivedas irrational and therefore irrelevant. Moreover, Evans (2001) argued that emotions are associated with weakness of both thinking and action.

However, the classic rational choice strategy emanates from the rational choice theory which supposes that voters make their voting decisions in ne with their own self-interest (Dean \&Croft, 2009) These notions of classic rational choice have suggested that voters make their electoral decisions just as if they were buying products or services. However, Habermas (1992) argued that currently political party/ candidate identificationand information search has been condensed into images, signs, and symbols, and it weakens the democratic decision-making process. This encourages mostly a homogenous response to political issues which can perpetrateVoters manipulation through political communications. Lupia, MeCubbins and Popkin (2000) took a more extensive view of classic rational choice and suggested that 'a rational choice is one that is grounded in motives, irrespective of what these motives may be.

\section{Confirmatory Decision-Making}

Confirmatory decision-making is one of the decision strategies identified by Lau and Redlawsk (2013) as "models of decision making" that are used by citizens in making voting decisions. However, it started in 1960, when an English psychologist called Peter Wason coined the term" confirmation bias" (Yeoung, 2019). Confirmatory decision-making strategy is the direct opposite of the classic rational choice, it occurs when people misconstrue newly existing information as supporting previously held beliefs, even when there is no clear evidence for its validity (Akerlof, 1989). Teri (2018) argued that confirmatory decision-making strategy is the inclination to gather information even in an objective search and make voting decisions that are in consonance with the voters already existing beliefs. This type of bias has led to the perpetration of "fake news" that is passed on withoutexamination on social media platforms and wrong voting decisions (Hunjra, Salman, \&Lubna, 2016). Confirmatory decision-making is, in essence, when a voter makes a voting decision in view of new pieces of information from the world around him in a subjective, misguided manner, based on his/her prior opinion (Kosnik,2007). According to Lodge \& Taber (2013) with the confirmatory decision-making strategy, information search is more often passive than active. Eyal, Mani and Far (2017) opined thatconfirmatory decision-making strategy is a prejudice that seeks, interprets information, and make decisions that indorses pre-existing beliefs. It is insidious because it affects the choices of voters during elections. Once a voter has formed his/her opinion concerning a political party/candidate, the argument goes, further pieces of evidence on the abilities of that political party/candidate can be used to support both a positive, or a negative, assessment of that very same candidate /political party, depending on the initial beliefs of the voter (Hunjra, Salman \& Lubna, 2016) Confirmatory decision-making strategy affects how

@ECRTD-UK https://www.eajournals.org/

ULR: https://doi.org/10.37745/bjms.2013 
British Journal of Marketing Studies

Vol. 10, Issue 1, pp.13-31, 2022

Print ISSN: 2053-4043(Print),

Online ISSN: 2053-4051(Online)

voters perceive the world around them, how they remember things, how they interpret the information available to them and how they process what is otherwise neutral information -and it tends to be favorable to their beliefs (Ayal et al. 2017). According to Yeoung (2019) confirmatory decision making is a bias and a common mental error that occurs when a pre-existing belief impedes on the way we think, make decisions, and lake actions. When voters have a belief or hypothesis in their minds that they think is true knowingly or unknowingly, they are more likely to seek more evidence to prove it right and make decisions that are aligned with their beliefs.

\section{Fast \& Frugal Decision-Making}

The Fast and Frugal Decision-Making strategy is based On Herbert Simon's bounded rationality theory Simon $(1956 ; 1972 ; 1982)$. It is based on heuristics, that are construed as a trade-off between the confines of the human mind and the computing performance needed for solving complex problems (Schilirò, 2017). GerdGigerenzer proposed a psychological approach based on fast \& frugal heuristics to examine simple substitutes to a full rationality analysis as a tool between for decision making. He maintained that simple heuristic's habitually lead to better decisions than the theoretically optimal procedure (Gigerenzer, Hertwig and Pachur, 2011). In applied settings, people make decisions under different degrees of obscurity, that is, when risks are unknown or cannot be calculated. In such situations, decisions can be made using fast-and-frugal decisionmaking strategy or heuristics (Sebastian, Waeger, Marewski, \&Gigerenzerd, 2016). Fast \& frugal decision-making refers to the application of environmentally lucid heuristics, such as the recognition heuristic, which are rooted in the psychological capabilities that we have evolved as human animals (e.g., memory and perceptual systems). It is referred to as "fast \& frugal" because they are effective under conditions of bounded rationality "when information, knowledge, time, and the ability to compute are limited (Goldstein \& Gigerenzer,2002). Fast and frugal decisionmaking strategy is a simple, task-specific decision strategy that is an aspect of a voters decisionmaking repertoire of cognitive strategies for making voting decisions (Gigerenzer\& Goldstein, 1996; Gigerenzer\& Todd, 1999). According to Lau et al, (2018), fast \& frugal decision-making strategy assumes that voters are driven mostly by efficiency, actively seeking only the most diagnostic information that will allow them to quickly make the correct voting choice. They maintained that Information-Seeking should be limited to the one or two most Important/ diagnostic criteria, but those few criteria Should bejustly applied to every alternative in the choice set-that is, shallow but comparable search Fast and frugal heuristics are rules of thumb for decision makings they are easy, task specific decision strategies that are part of a decision maker s collection of cognitive strategies for solving problems and decision tasks (Schiliro, 2017). Reimer and Rieskamp (2007) argued that the fast \& frugal heuristics recognizes not only the result of the decision-making process but also the process itself. It consists of Simple building blocks that specify how information is searched for (search rule), when to stop Information search (stopping rule), and how the processed information is integrated into a decision (decision rule). Fast $\&$ frugal decision- making strategy yield voters' decisions that is ecologically rational rather than logically consistent.

@ECRTD-UK https://www.eajournals.org/

ULR: https://doi.org/10.37745/bjms.2013 
British Journal of Marketing Studies

Vol. 10, Issue 1, pp.13-31, 2022

Print ISSN: 2053-4043(Print),

Online ISSN: 2053-4051(Online)

\section{Political Party Brand Competence and Voters Decision-Making}

The cultivation and maintenance of a brand is becoming increasingly important as politicians seek to connect with constituents. through the lens of social cognitive and group dynamics, Benne Malone., Cheatham and Saligram (2019) study on "the impact of perceptions of politician brand warmth and competence on voting intentions was aimed at understanding the impact of evaluations of politician brands on voter intentions. Their three studies utilized the social cognition constructs of warmth and competence from the stereotype content model (SCM) and Brands as Intentional Agents Framework (BIAF) to evaluate the impact of brand perceptions on voting intentions, comparing fit between the models. The data from their study Support Perceptionsof warmth and competence as significant predictors of voting intentions. Dependent upon whether the politician is being evaluated as a person. BIAPF or SCM predicts the dimension that will be most impactful. These patterns persist in the absence of full information. As expected, voting intentions increased significantly when the voter was of the same (VS Opposing) party as that of the candidate. Bennett et, al. (2019) Conducted their study during an election year, at which point, evaluations of politicians are susceptible to the current political climate and the predominantly two party political system in which the studies were conducted. The design of Studies 2 and 3 addressed some of the limitations of their study. Results from Bennett el, al., (2019) point toward the interrelated nature of warmth and competence perceptions and the usefulness of applying both BIAF and SCM to understand how voters view politicians and the drivers of voting intentions.practically, their study evidenced the depth to which perception of candidates' impact voting intent establishing politicians' unique position as both brands and people. Kaur and Sohal. (2019) in their study on "examining the relationships between political advertisements, party brand personality voter satisfaction and party loyalty, observed that although the concept of political party brand personality has received substantial recognition in the political marketing literature, however, no study as yet has contributed in identifying a causal relationship between the party brand personality and voter behavior. Therefore, their study was conducted with the aim to address this gap in the academic literature by determining the relationship between the multifaceted advertising-brand personality-satisfaction-loyalty constructs in political context. The sample for their study consisted of 930 responses drawn from the major cities of Punjab state in India through multistage stratified random sampling. AMOS-based structural equation modelling was used to test their proposed model. Results from their study revealed that voters attitude towards political advertisements had a significant effect Ontheir satisfaction andloyalty when brand personality had a mediating role in this effect. Additionally, the influence of party brand personality on satisfaction and loyalty of voters was different for the selected four political parties. The outcome from their study carries strong implications for the political parties and the political marketers to develop pertinent marketing and communication strategies that are consistent with their personality traits, with an endeavor to enhance the satisfaction and loyalty of Voters. Based on the foregoing, this study hypothesizes as followings:

Ho1: Political party brand competence has no significant relationship with classic rational choice in Nigeria.

Ho2: Political party brand competence has no significant relationship with confirmatory decision-making in Nigeria.

@ECRTD-UK https://www.eajournals.org/

ULR: https://doi.org/10.37745/bjms.2013 
British Journal of Marketing Studies

Vol. 10, Issue 1, pp.13-31, 2022

Print ISSN: 2053-4043(Print),

Online ISSN: 2053-4051(Online)

Ho3: Political party brand competence has no significant relationship with fast \& frugal in Nigeria decision-making in Nigeria.

\section{METHODOLOGY}

Primary data was generated through structured questionnaire. The target population of this study was eighty four million, four thousand and eighty four $(84,004,084)$. Given an accessible population of twenty six million, six hundred and thirty four thousand six hundred and five $(26,634,605)$ within the six geo-political zones in Nigeria, the sample size of 384 was determined using calculated using the Taro Yamane's formula for sample size determination. The reliability of the instrument was achieved by the use of the Cronbach Alpha coefficient with all the items scoring above 0.70 . The hypotheses were tested using the Pearson Product Moment Correlation Coefficient with the aid of Statistical Package for Social Sciences version 23.0. The tests were carried out at a $95 \%$ confidence interval and a 0.05 level of significance.

\section{DATA ANALYSIS AND RESULTS}

Table 1: Correlations for Brand Competence and Voters' Decision Making

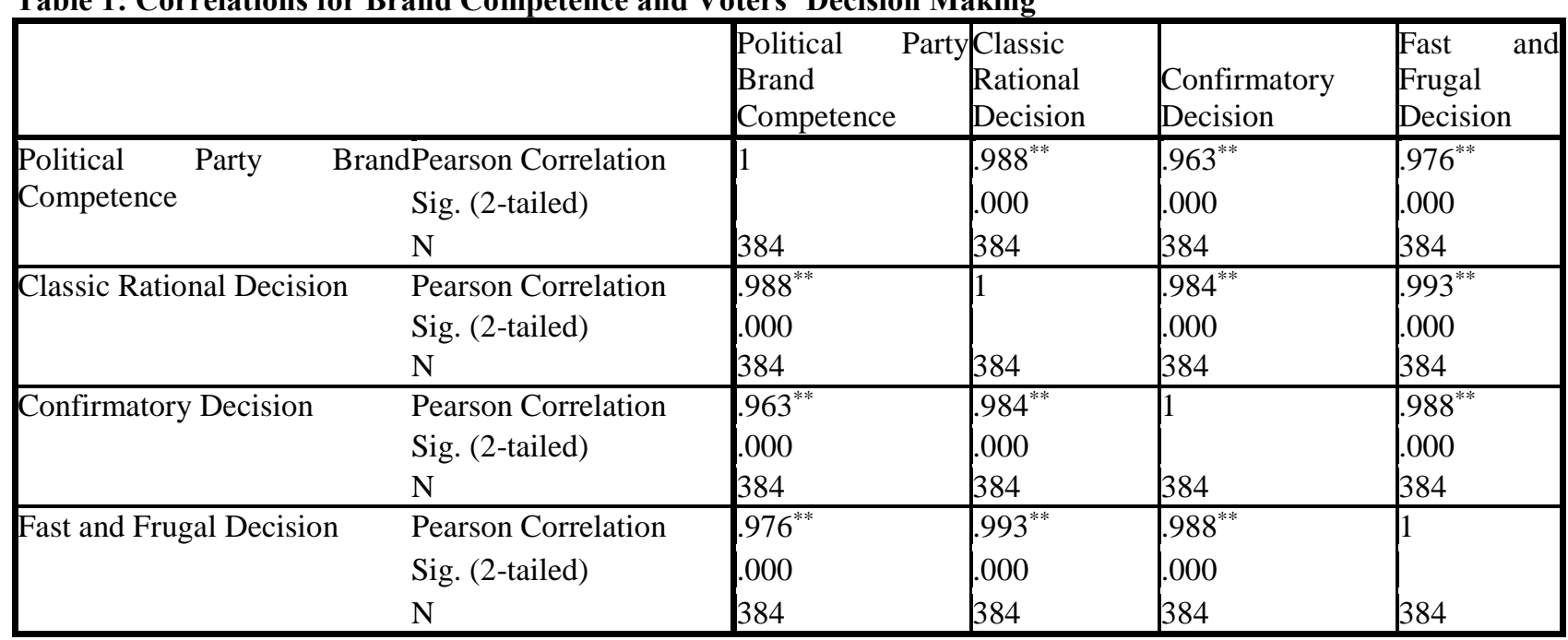

**. Correlation is significant at the 0.01 level (2-tailed).

\section{Source: SPSS Output}

Ho1: Political party brand competence has no significant relationship with classic rational choice in Nigeria.

The result of correlation matrix obtained between political party brand competence and classic rational decision is shown in Table 1 . The correlation coefficient of 0.988 confirms the degree and strength of this relationship and it is significant at $\mathrm{p} 0.000<0.01$. The coefficient represents a very strong correlation between the variables. Therefore, based on observed findings the null hypothesis 
British Journal of Marketing Studies

Vol. 10, Issue 1, pp.13-31, 2022

Print ISSN: 2053-4043(Print),

Online ISSN: 2053-4051(Online)

earlier stated is hereby rejected and the alternate upheld. Thus, there is a significant relationship between political party brand competence and classic rational decision in Nigeria.

Ho2: Political party brand competence has no significant relationship with confirmatory decision in Nigeria.

The result of correlation matrix obtained between political party brand competence and confirmatory decision is shown in Table 1 . The correlation coefficient of 0.963 confirms the degree and strength of this relationship and it is significant at p $0.000<0.01$. The coefficient represents a very strong correlation between the variables. Therefore, based on observed findings the null hypothesis earlier stated is hereby rejected and the alternate upheld. Thus, there is a significant relationship between political party brand competence and confirmatory decision in Nigeria.

Ho3: Political party brand competence has no significant relationship with fast and frugal decision in Nigeria.

The result of correlation matrix obtained between political party brand competence and fast and frugal decision is shown in Table 1 . The correlation coefficient of 0.976 confirms the degree and strength of this relationship and it is significant at $\mathrm{p} 0.000<0.01$. The coefficient represents a very strong correlation between the variables. Therefore, based on observed findings the null hypothesis earlier stated is hereby rejected and the alternate upheld. Thus, there is a significant relationship between political party brand competence and fast and frugal decision in Nigeria.

\section{DISCUSSION OF FINDINGS}

One of the thrusts of this study was to investigate the association between political party brandCompetence and voters' decision making in the political marketing system in Nigeria. This study found positive correlational values and a very strong linear association between the political party brand competence and the three indicants of voters' decision making in the Nigeria political marketing system. The findings from this study is in line with Bennett., Malone., Cheatham and Saligram (2019) study on "the impact of perceptions of politician brand warmth and competence on voting intentions" which was aimed at understanding the impact of evaluations of politician brands on voter intentions. Their three studies utilized the social cognition constructs of warmth and competence from the stereotype content model (SCM) and Brands as Intentional Agents Framework (BIAF) to evaluate the impact of brand perceptions on voting intention, comparing fit between the models. Their first study established the impact of these perceptions on existing politicians. Their second study replicated these effects while controlling for party affiliation and extraneous factors and explicitly studied politicians as brands. Their third study examined the formation of perceptions and assumptions when full information is unavailable. Social cognition and group dynamics drive responses to political brand.

The present study also supports the findings from the study of Kaur and Sohal, (2019) whose study was focused on. "Examining the relationships between political advertisements, party brand

@ECRTD-UK https://www.eajournals.org/

ULR: https://doi.org/10.37745/bjms.2013 
British Journal of Marketing Studies

Vol. 10, Issue 1, pp.13-31, 2022

Print ISSN: 2053-4043(Print),

Online ISSN: 2053-4051(Online)

personality, Voter satisfaction and party loyalty". Their study established a strong relationship ship between political advertisements, party brand personality, voter satisfaction auld party loyalty" Theoretically, this study confirms the question asked and answer offered by Guzmán and Sierra (2009) who forthrightly asked, "Are Political Candidates Brands?" and argued for a definitive affirmation. Positing that brand image has shifted from the party to the candidate, they built a comprehensive framework for evaluating candidates through 58 traits based on the brand personality schema. Their Study adopted national household survey, their data pointed to five basic dimensions of politician brand personality: capability, openness, empathy, agreeableness, and handsomeness. The most compelling aspect of Guzmán and Sierra's research (2009) is not the attempt to determine whether politicians theoretically merit the appellation "brand," but rather, the confirmation that, consumers (voters in this case) actively perceive and respond to candidates as such (Guzmán \& Sierra, 2O09). Other results, developed in different contexts, Substantiate the politician's perception as a brand, including those on candidate associations in the 2005 Polish presidential election (Cwalina \& Falkowski, 2015), on the role of community organizers in growing local Australian politicians' brands, and on Bill Clinton and Tony Blair's brand efficacy as incumbents. If individual politicians are repeatedly regarded as brands, and are thus Susceptible to the same defining judgments of warmth and competence, to what degree do such Judgments affect voting intentions?

The findings from this present study provides answer to this effect.results from Bennett el, al. (2019) point toward the interrelated nature of warmth and competence perceptions and the usefulness of applying both BIAF and SCM to understand howvoters view politicians and the drivers of voting intentions. Practically, their study evidencedthe depth to which perceptions of candidate's impact voting intent, establishing politicians unique position as both brands and people. Kaur and Sohal (2019) in their study on "examining the relationships between political advertisements, party brand personality, voter satisfactionand party loyalty", observed that although the concept of political party brand personality has received substantial recognition in the political marketing literature, however, no study as yet has contributed in identifying a causal relationship between the party brand personality and voter behavior. Therefore, their study was conducted with the aim to address this gap in the academic literature by determining the relationship between the multifaceted advertising-brand personality satisfaction-loyalty constructs in political context. The sample for their study consisted of 930 responses drawn from the major cities of Punjab state in India through multistage stratified random sampling. AMOS-based structural equation modelling was used to test their proposed model. Results from their study revealed that voters attitude towards political advertisements had a significant effect on their satisfaction and loyalty when brand personality had a mediating role in this effect. Additionally, the influence of party brand personality on satisfaction and loyalty of voters was different for the selected four political parties. The outcome from their study carries strong implications for the political parties and the political marketers to develop pertinent marketing and communication strategies that are consistent with their personality traits, with an endeavor to enhance the satisfaction and loyalty of voters.

@ECRTD-UK https://www.eajournals.org/

ULR: https://doi.org/10.37745/bjms.2013 
British Journal of Marketing Studies

Vol. 10, Issue 1, pp.13-31, 2022

Print ISSN: 2053-4043(Print),

Online ISSN: 2053-4051(Online)

\section{CONCLUSION AND RECOMMENDATION}

The study concludes that when political parties adopt and build brand competence it has a positive influence on voters' decision making in Nigeria.

The study recommends that political parties should always present brands (candidates) for elective positions based on personality of such candidates especially with regards to brand competence.

\section{REFERENCES}

Aaker, J. (1997), "Dimension of Brand Personality," Journal of Marketing Research, 34 (August), 347-356.

Achor, P.N. \& Moguluwa, S.C. (2012) political marketing: marketing communication and politice , Enugu: Oktek Nigeria Ltd.

Achor, P.N., Nwachukwu, C., \& Udensi, M.I (2016). Politics unusual: Rethinking Nigeria political terrain through political marketing strategies. European journal of business and management 8(20), 103-112

Akerlof, G. A., \& Katz, L. F. (1989). Workers' trust funds and the logic of wage profiles. The Quarterly Journal of Economics, 104(3), 525-536.

Allen, C.L. (1952). Modern Welfare Economics and Public Policy. Southern Economic Journal, $19,28-36$.

Andrews, Josephine T. and Jackman, Robert, 'Strategic Fools: Electoral Rule Choice Under Extreme Uncertainty', Electoral Studies, 24/1 (2005), pp. 65-84

Barnes, B. R., Leonidou, L. C., Siu, N. Y., \& Leonidou, C. N. (2015). Interpersonal factors as drivers of quality and performance in Western-Hong Kong interorganizational business relationships. Journal of International Marketing, 23(1), 23-49.

Beck, C., Kosnik, C., \& Rowsell, J. (2007). Preparation for the first year of teaching: Beginning teachers' views about their needs. The New Educator, 3(1), 51-73.

Becker, G. (1976); The Economic Approach to Human Behavior, Chicago and London: The University of Chicago Press, 3-14.

Bennett, A. M., Malone, C., Cheatham, K., \& Saligram, N. (2019). The impact of perceptions of politician brand warmth and competence on voting intentions. Journal of Product \& Brand Management.

Blanchflower, D.G. \& A.J. Oswald. (1998). What makes an entrepreneur? Journal of Labor Economics, 16, 26-60

Braha, D., \& De Aguiar, M. A. (2017). Voting contagion: Modeling and analysis of a century of US presidential elections. PloS one, 12(5), e0177970.

Brams, S. (1985). Rational politics, decisions, games and strategy. London: Harcourt Brace

Brogan, J. V. (2001). The mirror of enlightenment: The rational choice debate. The Review of Politics, 58(4), 793-806.

Chong, D. (2013). Degrees of rationality in politics. In L. Huddy, D. O. Sears, \& J. S. Levy (Eds.), Oxford handbook of political psychology (2nd Ed.), New York, NY: Oxford University Press.

@ECRTD-UK https://www.eajournals.org/

ULR: https://doi.org/10.37745/bjms.2013 
British Journal of Marketing Studies

Vol. 10, Issue 1, pp.13-31, 2022

Print ISSN: 2053-4043(Print),

Online ISSN: 2053-4051(Online)

Collins, Allan M. , and Loftus, Elizabeth F. (1975), “A Spreading Activation Theory of Semantic Processing," Psychological Review, 82, 407-28.

Cwalina, W., Falkowski, A., \& Newman, B. I. (2015). Persuasion in the political context: Opportunities and threats. In D. W. Stewart (Ed.), Handbook of persuasion and social marketing (Vol. 1, pp. 61-128). Santa Barbara, CA: Praeger.

Cwalina,W \& Falkowski, A (2014). Political branding: Political candidate positioning based on inter-object associative affinity index, Journal of political marketing 1, 152-174 http://dx.doi.org/10.1080/15377857.2014.990842

Davies, G., Rojas-Mendez, J., Whelan, S., Mete, M. and Loo, T. (2018) Brand personality: theory and dimensionality. Journal of Product \& Brand Management, 27 (2). 115-127. http://centaur.reading.ac.uk/88534/

De Chernatony Leslie, Malcolm McDonald (1998), Creating powerful brands in consumer, service and industrial markets, 2nd ed., Butterworth Heinemann, p. 421.

de Groot, A. (1978). Thought and choice and chess. The Hague: Mouton. (Original work published 1946).

Downs, A. (1957). An economic theory of democracy. New York: Harper Row

Downs, A. (1957); An Economic Theory of Political Action in a Democracy, The Journal of Political Economy, 65( 2), 135 - 150.

Downs, Anthony, An Economic Theory of Democracy (New York: Harper and Row, 1957)

Dunleavy, P., \& Margetts, H. (1995). Understanding the dynamics of electoral reform. International political science review, 16(1), 9-29.

Edlin, A., Gelman, A., \& Kaplan, N. (2007). Voting as a rational choice: Why and how people vote to improve the well-being of others. Rationality and society, 19(3), 293-314.

Elster, J. (1989); Social Norms and Economic Theory, Journal of Economic Perspectives, American Economic Association, 3(4), pages 99-117.

Epstein, R. M., \& Hundert, E. M. (2002). Defining and assessing professional competence. Journal of the American Medical Association, 287(2), 226-235. http://dx.doi.org/10.1001/jama.287.2.226

Evans, Dylan, 2001, Emotion: The Science of Sentiment, Oxford: Oxford University Press.

Fernandez-Vazquez, P. (2014). And yet it moves: The effect of election platforms on party policy images. Comparative Political Studies, 47(14), 1919-1944.

French, A., \& Smith, G. (2010). Measuring political brand equity: a consumer oriented approach. European Journal of Marketing.

Friedman, M. (1953); Essays in Positive Economics, Chicago: University of Chicago Press. pp. $15,22,31$.

Gigerenzer G., Hertwig R. and T. Pachur (eds.) (2011). Heuristics: The Foundations of Adaptive Behavior. New York: Oxford University Press.

Gigerenzer, G., \& Goldstein, D. G. (1996). Reasoning the fast and frugal way: models of bounded rationality. Psychological Review, 103(4), 650-669.

Gigerenzer, G., Todd, P. M., \& the ABC Research Group (1999). Simple heuristics that make us smart. New York, NY: Oxford University Press.

Goldstein, D. G., \& Gigerenzer, G. (2002). Models of ecological rationality: The recognition heuristic. Psychological Review, 109, 75-90.

@ECRTD-UK https://www.eajournals.org/

ULR: https://doi.org/10.37745/bjms.2013 
British Journal of Marketing Studies

Vol. 10, Issue 1, pp.13-31, 2022

Print ISSN: 2053-4043(Print),

Online ISSN: 2053-4051(Online)

Gorbaniuk, O. Kusak,K. ,kogut, A \& Kustos, M.(2014)Dimensions of political party personality perception. Journal of political marketing 35-63 dx.doi.org/10.1080/15377857.2014.990840

Green, D. P. and Shapiro, I. (1996); Pathologies of Rational Choice Theory: A Critique of Applications in Political Science, New Haven, CT: Yale University Press.

Grüne-Yanoff, T. (2012). Old wine in new casks: Libertarian paternalism still violates liberal principles. Social Choice and Welfare, 38(4), 635-645.

Guzmán, F., \& Sierra, V. (2009). A political candidate's brand image scale: Are political candidates brands?. Journal of Brand Management, 17(3), 207-217.

Habermas, J. (2001) Learning from Catastrophe? A Look Back at the Short Twentieth Century, in Habermas, J. The Postnational Constellation - Political Essays, Cambridge: Polity.

Hafenbrädl, S., Waeger, D., Marewski, J. N., \& Gigerenzer, G. (2016). Applied decision making with fast-and-frugal heuristics. Journal of Applied Research in Memory and Cognition, 5(2), 215-231.

Hartig, J.; Klieme, E. \& Leutner, D. (Eds.) (2008). Assessment of Competencies in Educational Contexts: State of the Art and Future Prospects. Göttingen: Hogrefe \& Huber

Hoeffler, S. Keller, K. L. (2002) Building Brand Equity through corporate societal marketing, Journal of Public Policy and Marketing, 21, (1), 78-89,

Hogarth, R. M. and Reder, M. W. (1987); Rational Choice: The Contrast between Economics and Psychology, Chicago and London: The University of Chicago Press.

Ibeanu, O., \& Orji, N. (2014). Approaches to Civic and Voter Education: Nigeria's Experience in Comparative Perspective. Nigeria: Independent National Electoral Commission.

Jain, V., Chawla, M., Ganesh, B. E., \& Pich, C. (2018). Exploring and consolidating the brand personality elements of the political leader. Spanish Journal of Marketing-ESIC.

Kaur, H., \& Sohal, S. (2019). Examining the relationships between political advertisements, party brand personality, voter satisfaction and Party Loyalty. Journal of Indian Business Research.

Keller, K. L., \& Richey, K. (2006). The importance of corporate brand personality traits to a successful 21st century business. Journal of Brand management, 14(1), 74-81.

Keller, K. L., \& Richey, K. (2006). The importance of corporate brand personality traits to a successful 21st century business. Journal of Brand management, 14(1), 74-81.

Kotler, P. (1975). Overview of political candidate marketing. ACR North American Advances.

Kotler, P. (2000) Marketing Management (Millennium Edition). Upper Saddle River, NJ: Prentice Hall International.

Krugman, H. E. (1965). The impact of television advertising: learning without involvement. Public Opinion Quarterly, 29, 349-356.

Lau, R. R., \& Redlawsk, D. P. (2001a). Advantages and disadvantages of cognitive heuristics in political decision making. American Journal of Political Science, 45(4), 951-971.

Lau, R. R., Kleinberg, M. S., \& Ditonto, T. M. (2018). Measuring voter decision strategies in political behavior and public opinion research. Public Opinion Quarterly, 82(S1), 911-936.

Lau, R. R., Patel, P., Fahmy, D. F., \& Kaufman, R. R. (2013). Correct Voting Across Thirty-Three Democracies: A Preliminary Analysis. British Journal of Political Science, 1-21.

@ECRTD-UK https://www.eajournals.org/

ULR: https://doi.org/10.37745/bjms.2013 
British Journal of Marketing Studies

Vol. 10, Issue 1, pp.13-31, 2022

Print ISSN: 2053-4043(Print),

Online ISSN: 2053-4051(Online)

Lees-Marshment, J. 2014. Political Marketing 2nd Edition: Principles and Applications: Taylor \& Francis

Leiter, Debra, April K. Clark and Michael Clark. 2019. "Winners and Losers Reconsidered: Party Support, Character Valence, and Satisfaction With Democracy." European Political Science Review 11(3):285-300.

Lewis, J. P. 2008. Is Civic Education the Answer? The Futile Search for Policy Solutions to Youth Political Apathy. Available at: http://www.crcee.umontreal.ca/.../Is\%20CivicEducation\%20the\%20Answer...

Li, Y., Ashkanasy, N. M., \& Ahlstrom, D. (2010). Complexity theory and affect structure: A dynamic approach to modeling emotional changes in organizations. In Emotions and organizational dynamism. Emerald Group Publishing Limited.

Luca, N. R., \& Suggs, L. S. (2013). Theory and model use in social marketing health interventions. Journal of Health Communication: International Perspectives, 18, 20-40.

Lupia, A., McCubbins, M. D., \& Popkin, S. L. (2000). Beyond rationality: Reason and the study of politics. Elements of reason: Cognition, choice, and the bounds of rationality, 1-20.

Maibach, E.W. (1993) 'Social marketing for the environment: Using information campaigns to promote environmental awareness and behaviour change', Health Promotion International 8(3): 209-23

Mavondo F.T and Rodrigo E.M (2001) the effect of relationship dimensions on interpersonal and inter organizational commitment in organizations conducting business between Australia and China, Journal of Business Research, 52, 2, 111-21

McClelland, D. C. (1973). Testing for competence rather than testing for «intelligence». American Psychologist, 28(1), 1-14

McCroskey, J. C., \& Young, T. J. (1981). Ethos and credibility: The construct and its measurement after three decades. Communication Studies, 32(1), 24-34.

McGraw, Kathleen M. (2000): Contributions of the cognitive approach to political psychology. Political Psychology, 21(4), pp. 805-824.

Monroe, Kristen R.; Hankin, James et al. (2000): The psychological foundations of identity politics. In Nelson W. Polsby, ed: Annual Review of Political Science, 3, pp. 419-447.

Niazi, G. S. K., Siddiqui, J., Alishah, B., \& Hunjra, A. I. (2012). Effective advertising and its influence on consumer buying behavior. Information management and business review, 4(3), 114-119.

Niemi, Richard G. \& Junn, Jane (1998): Civic Education. What Makes Students Learn? New Haven, London: Yale University Press.

O'Shaughnessy, J. and O'Shaughnessy, N. J. (2000), "Treating the nation as a brand: Some neglected issues", Journal of Macromarketing, 20( 1) 56-64.

OECD. (2002). Definition and selection of competencies (DeSeCo): Theoretical and conceptual foundations. Strategy paper JT00132752 Retrieved January 7, 2008, from http://www.portal-stat.admin.ch/deseco/deseco_strategy_paper_final.pdf

Ogu, M. I. (2013). Rational Choice Theory: Assumptions, Strengths and Greatest Weaknesses in Application Outside the Western Milieu Context. Arabian Journal of Business and Management Review (Nigerian Chapter) Vol, 1(3), 90-99.

@ECRTD-UK https://www.eajournals.org/

ULR: https://doi.org/10.37745/bjms.2013 
British Journal of Marketing Studies

Vol. 10, Issue 1, pp.13-31, 2022

Print ISSN: 2053-4043(Print),

Online ISSN: 2053-4051(Online)

Osborne, Ken 2000. 'Public Schooling and Citizenship Education in Canada', Canadian Ethnic Studies, 32(1): 8-37.

Paul, H., \& John, M. (1995). The relationship of reputation and credibility to brand success. Journal of Consumer Marketing, 12(4), 5-10.

Peattie, S., \& Peattie, K. (2003). Ready to fly solo? Reducing social marketing's dependence on commercial marketing theory. Marketing theory, 3(3), 365-385.

Petty, R. E., \& Cacioppo, J. T. (1979). Issue involvement can increase or decrease persuasion by enhancing message-relevant cognitive response. Journal of Personality and Social Psychology, 37 (October), 1915-1926.

Pich, C., Armannsdottir, G., Dean, D., Spry, L., \& Jain, V. (2019). Problematizing the presentation and reception of political brands: The strategic and operational nature of the political Brand alignment model. European Journal of Marketing.

Radnitzky, G., \& Bernholz, P. (Eds.). (1987). Economic imperialism: The economic approach applied outside the field of economics. New York: Paragon House Publishers.

Rauch, A. \& M. Frese. (2007a). Let's put the person back into entrepreneurship research: A metaanalysis on the relationship between business owners' personality traits, business creation, and success. European Journal of Work and Organizational Psychology, 16, 353-385.

Reimer, T., \& Rieskamp, J. (2007). Fast and frugal heuristics. Encyclopedia of social psychology, 346-348.

Richen, D. S. and Salganik, L. H. (2003). Key competencies for a successful life and a wellfunctioning society. Cambridge: Hogrefe \& Huber

Rothschild, M. L. (1979). Advertising strategies for high and low involvement situations. In J. Maloney, \& B. Silverman (Eds.), Attitude Research Plays for High Stakes (pp. 74-93). Chicago: American Marketing Association.

Rutter, Richard, Chalvatzis, Konstantinos, Roper, Stuart and Lettice, Fiona (2017) Branding Instead of Product Innovation: A Study on the Brand Personalities of the UK's Electricity Market. European Management Review. ISSN 1740-4754

Schilirò, D. (2015). Psychology into economics: fast and frugal heuristics.

Schneider, H. 2004. "Branding in Politics - Manifestations, Relevance and Identity-Oriented Management." Journal of Political Marketing 3 (3): 41-67.

Simon, H. A. (1956). Rational choice and the structure of the environment. Psychological Review, 63, 129-138.

Simon, H.A. (1972). Theories of bounded rationality. In McGuire, C.B. and R. Radner (eds.), Decision and organization. Amsterdam: North Holland.

Simon, H.A. (1982). Models of bounded rationality. Vol.2.Behavioral economics and business organization. Cambridge (MA): The MIT Press.

Simonton, D. K. (2003). Expertise, competence, and creative ability: The perplexing complexities.

Sleurs, W. (Ed.) (2008), "Competencies for ESD (education for sustainable development) teachers: a framework to integrate ESD in the curriculum of teacher training institutes", Comenius 2.1 project 118277-CP-1-2004-BE-Comenius-C2.1, available at: www.ensi.org/Projects/ Teacher_Education/CSCT/ 15(11).

Smith, G. 2009. "Conceptualizing and Testing Brand Personality in British Politics." Journal of Political Marketing 8 (3): 209-232.

@ECRTD-UK https://www.eajournals.org/

ULR: https://doi.org/10.37745/bjms.2013 
British Journal of Marketing Studies

Vol. 10, Issue 1, pp.13-31, 2022

Print ISSN: 2053-4043(Print),

Online ISSN: 2053-4051(Online)

Smith, G., \& French, A. (2009). The political brand: A consumer perspective. Marketing theory, 9(2), 209-226.

Solhaug, Trond (2003): Utdanning til demokratisk medborgerskap [Education for Democratic Citizenship]. Oslo: Universitetet i Oslo, Utdanningsvitenskapelig fakultet.

Swedberg, R. (1990). Economics and sociology. Princeton, NJ: Princeton University Press. R

Torney-Purta, Judith (1992): Cognitive representations of the political system in adolescents: the continuum from pre-novice to expert. In Helen Haste \& Judith Torney-Purta, ed: The Development of Political Understanding: A New Perspective, pp. 11-25. San Francisco: Jossey-Bass Publishers.

Wang, B., Childerhouse, P., Kang, Y., Huo, B., \& Mathrani, S. (2016). Enablers of supply chain integration: interpersonal and interorganizational relationship perspectives. Industrial Management \& Data Systems.

Weinert, F. E. (2001). Concept of Competence: A Conceptual Clarification. In: D. S. Rychen \& L. H. Salganik (Eds.): Defining and Selecting Key Competencies. Göttingen: Hogrefe \& Huber

Wilcox, Y., \& King, J. (2014). A professional grounding and history of the development and formal use of evaluator competencies. Canadian Journal of Program Evaluation, 28(3).

Wyer, Robert S., \& Srull, Thomas K. (1989), "Person Memory and Judgment," Psychological Review, 96 (1), 58-83.

Zhao, H. \& S.E. Seibert. (2006). The big five personality dimensions and entrepreneurial status: A metaanalytical review. Journal of Applied Psychology, 91, 259-271.

@ECRTD-UK https://www.eajournals.org/

ULR: https://doi.org/10.37745/bjms.2013 